\author{
육경 조직판 이식이 사슴뿔의 성장에 미치는 영향 \\ 김상우* . 최순호* . 상병돈* . 김영근* . 이승수* . 상병찬** . 서길웅** \\ 농촌진흥청 축산연구소*, 충남대학교**
}

\title{
Influences of Pedicle Flap-graft Transplantation on Antler Growth in Deer
}

\author{
S. W. Kim*, S. H. Choi*, B. D. Sang*, Y. K. Kim*, S. S. Lee*, B. C. Sang** and K. W. Seo** \\ National Livestock Research Institute, R.D.A.*, \\ Department of Dairy Science, Chung Nam National University**
}

\begin{abstract}
The development of flip-graft, yield of antler and growth of antler in Sika deer, Red deer and Elk were investigated to establish the technology of transplantation of flip-graft. Pedicle flip-grafts were transplanted on the sides pedicle, on the midline of forehead and on the middle line of the skull. The success rate of transplantation was $42 \%, 5$ animals out of 12 . The yields of antler and number of point were $716 \mathrm{~g}$ and $1,071 \mathrm{~g}$, and 2.3 and 1.0 in control and donor of flip-graft, respectively in red deer. The length and weight of anther of recipient of flip-graft in elk were $17 \mathrm{~cm}, 302 \mathrm{~g}$. The length and weight of hard antler of recipient of flip-graft in red deer were $26 \mathrm{~cm}$ and $122 \mathrm{~g}$. Flip-graft should be transplanted on the scull after removal of the corium for strong adherence.
\end{abstract}

(Key words : Pedicle, Flip-graft, Transplantation, Antler, Deer)

$$
\text { I. 서 론 }
$$

발생학적 측면에서 사슴뿔의 발달을 조사한 다면 사슴뿔의 형태발생에 이어서 분화, 축의 결정, 형태형성에 관여하는 여러 조직들의 상 호 작용에 관여하는 메커니즘에 대한 의문을 가질 것이다. 이 의문에 대한 전통적인 연구 방법은 이식과 삭제를 통하여 그동안 수행되어 왔으며, 사슴뿔은 완전한 재생을 하는 유일한 포유동물의 부속기관으로 알려져 있다. 사슴뿔 이식술의 첫 번째 성공적인 실험은 레드디어 (Cervus elaphus)에서 Jaczewski(1956a, b)에 의해 수행되었으며, 그는 육경 혹은 사슴뿔 전체를
이식 조직판으로 사용하였다. 이식 실험을 하는 동안 뿔의 재생은 자주 관찰되었으며 뿔 주기의 동시성은 다른 사슴과 같았다. 또한 Jaczewski (1961; 1967)는 육경 전체 이식방법으로 눈과 전두골 사이에서 4 개의 뿔을 생산했으며, 육경 의 조각과 뿔의 일부분은 아직도 이식에 이용 되고 있다. Hartwig와 Schrudde (1974)는 노루의 정수리 뼈와 이마에 사슴뿔을 이식하는데 성공 했으며 이식된 골막은 피부 없이 조직판 방법 을 사용하였다. 이후 사슴뿔의 이식실험은 사슴 의 앞다리 장골에도 이식에 성공하였다. 이상을 종합해보면 뿔 성장 유도시험은 진사슴아과 (cervidae) 사슴의 뿔 발달 재생설 "regeneration

Corresponding author : S. W. Kim, Animal Genetic Resources Station, National Livestock Research Institute, R.D.A, Namwon, 590-830, Korea.

Tel : (063) 620-3531, E-mail : sikasw@rda.go.kr 
theory"(Jaczewski, 1961; Goss, 1965)에 의하여 설 명할 수 있으며, 외상은 사슴뿔의 성장에 강한 자극효과를 가지고 뿔 성장 유도에서 자장 중 요한 조직은 뿔 성장 자리로 추정하는 부위의 골막이며 이 골막의 이용은 두개골의 다른 부 위와 다른 골격 뼈 등에서 뿔 성장의 유도가 가능하다고 하겠다.

따라서 본 연구는 사슴뿔 성장의 관여하는 여러 가지 요인 중 조직판 이식이 사슴뿔 성장 에 미치는 영향을 구명하고자 실시하였다.

\section{․ 재료 및 방법}

\section{1. 공시가축 및 시험장소}

본 시험은 평균체중이 $36 \mathrm{~kg}$ 인 8개월령 수컷 꽃사슴(Cervus nippon), $60 \mathrm{~kg}$ 인 8개월령 수컷 레 드디어(Cervus elaphus) 및 $140 \mathrm{~kg}$ 인 8개월령 수 컷 엘크(Cervus canadensis)를 이용하여 1999년 1 월부터 12 월까지 총 12 개월간 축산연구소 축 산자원개발부 사슴사(충남 천안)에서 실시하였 다.

\section{2. 시험설계}

본 시험의 공시동물로서는 꽃사슴 수컷 4 두, 레드디어 수컷 4두 및 엘크 수컷 4두로 총 12 두를 공시하여 Table 1 과 같이 전두골 정중선 에 조직판을 이식하는 구(T1)와 육경에 조직판 을 이식하는 구(T2)의 2처리구로 나누어 각 처 리구당 꽃사슴, 레드디어 및 엘크를 각각 2두 씩 12 두를 임의 배치하였다.

이마와 육경에 이식은 한쪽의 조직판을 절단 하여 이식하였으며 반대쪽은 원래 상태로 그냥 두었다. 본시험에 공시된 레드디어 4두는 낙각
시기가 비슷하여 왼쪽과 오른쪽을 육경 절단구 와 대조구로 두고 조직판 채취 후의 녹용 생산 량을 조사하였다.

\section{3. 사슴의 보정}

사슴은 마취 전에 12 시간 절식을 시켰으며 마 취약은 Fentazine-10 (Fentanyl Citrate $0.8 \mathrm{mg} / \mathrm{ml}$, Azaperone $6.4 \mathrm{mg} / \mathrm{ml}$, Xylazine Hydrochloride 116.6 $\mathrm{mg} / \mathrm{ml}$, Parnell Laboratories Ltd, New Zealand)을 사용하였으며, 엘크의 두당 마취용량은 $1.3 \mathrm{ml}$ 를 사용하였으며, 레드디어는 $0.6 \mathrm{ml}$ 꽃사슴은 $0.4 \mathrm{ml}$ 를 사용하였다. 주사방법은 블루건을 사 용하여 근육 주사하였다. 마취사슴의 해독은 해 독제인 Contran-H (Yohimbine HCL $10.0 \mathrm{mg} / \mathrm{ml}$, Naloxone HCL $0.1 \mathrm{mg} / \mathrm{ml}$, Parnell Laboratories Ltd, New Zealand)를 마취용량의 2배를 경정맥 에 주사하여 해독을 시켰다.

\section{4. 조직판이식(flap-grafting)}

조직판(flap)은 육경(pedicle)의 길이가 $1 \mathrm{~cm}$ 에 서 $3 \mathrm{~cm}$ 정도 되었을 때 육경의 피부를 먼저 소독용 알코올(70\%)로 깨끗이 닦아낸 후 2차로 베타딘을 이용하여 소독한 다음 육경의 한쪽 생 장점 끝(tip)을 외과용 수술칼 10번(surgical blade \#10)을 사용하여 꽃사슴(Cervus nippon)은 0.4 $0.5 \mathrm{~cm}$ 의 두께로 절단하여 조직판으로 사용하 였으며, 레드디어(Cervus elaphus)와 엘크(Cervus canadensis)는 $0.5 \mathrm{~cm}$ 두께로 절단하여 조직판으 로 사용하였다. 절단된 육경부위는 염화제2철 을 이용하여 지혈을 실시한 후 절단부위는 상 처가 노출한 채로 그냥 두었으며, 반대편은 대 조구로 조직판을 채취하지 않았다. 조직판을 분리하기 전 먼저 마취된 사슴은 눈을 가리고

Table 1. Region of grafting and number of deer by species

\begin{tabular}{clcccc}
\hline \multirow{2}{*}{ Treatments } & \multirow{2}{*}{ Grafting region } & \multicolumn{3}{c}{ No. of deer } \\
\cline { 3 - 5 } & & Sika & Red deer & Elk \\
\hline \hline $\mathrm{T} 1$ & Flap-grafting on the middle line of the skull & 2 & 2 & 2 \\
$\mathrm{~T} 2$ & Flap-grafting on the pedicle & 2 & 2 & 2 \\
\hline
\end{tabular}


다리를 묶은 다음 수술실과 수술대가 없는 관 계로 스키드로더를 이용하여 수술대로 사용하 였다. 이식부위는 Fig 1에서 보는 바와 같으며 조직판 분리에 앞서 먼저 이식 부위인 이마 정 중선 중앙을 소독한 다음 이식 부위의 피부를 조직판의 지름(약 $1.2 \sim 2 \mathrm{~cm}$ )과 비슷하게 둥글 게 피부를 외과용 수술칼 10 번을 이용하여 품 종별로 한 마리씩 총 3마리 피부의 진피는 남 긴 체 표피만을 제거하고 바로 조직판을 이식 하였으며, 나머지는 품종별로 한 마리씩 3 마리 는 피부를 진피까지 제거한 후 다시 골막에 외 과용 수술 칼을 이용하여 두개골에 상처를 낸 후 조직판을 이식하였으며, 이식은 흡수성 봉 합사(chromic surgical gut)를 이용하여 봉합사 제거 없이 한번의 수술로 이식을 완료하였으며 이식 후에는 거즈를 붙여 마무리하였다. 이식 할 육경 부위는 조직판의 면적만큼 육경 둘레 에 피부를 제거하고 조직판을 이식하였다.
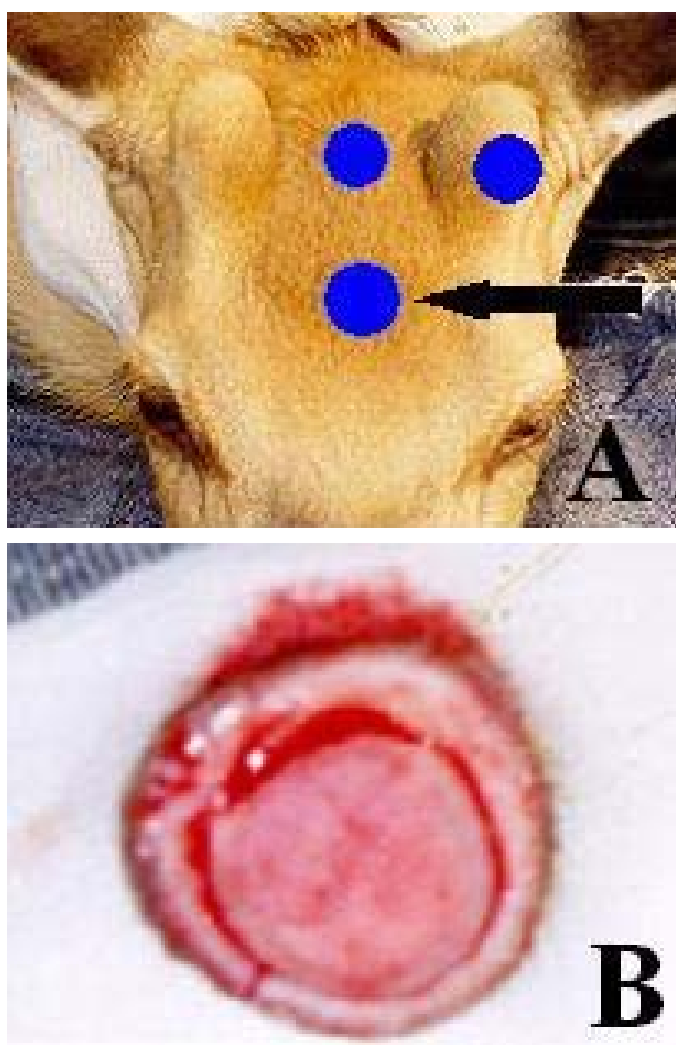

Fig. 1. (A) : Region of flap-grafting in elk, (B) : flap-graft of sika deer.

\section{5. 조사항목 및 방법}

\section{1) 조직판의 발달}

이식한 조직판의 발달은 이식한 부위 조직판 이 자라기 시작하여 $3 \sim 5 \mathrm{~cm}$ 길이가 되었을 때 까지를 육경으로 조사하였고, 그 이상 발육한 것은 사슴뿔로 분화가 일어났다고 보았다.

\section{2) 녹용생산량}

시험에 공시한 레드디어 4 두의 양쪽 사슴뿔 의 절각은 첫 뿔의 길이가 $25 \mathrm{~cm}$ 정도 되었을 때 절각을 하였으며, 재생뿔의 절각은 재생뿔 이 자라기 시작하여 외관상 녹용의 골화가 일 어나기 전에 절각을 하여 생녹용 상태에서 녹 용의 무게를 측정하였다. 조직판을 이식하여 사슴뿔이 자란 사슴은 엘크 1 두의 녹용이 앞이 마에 이식된 구에서 발육은 양호하였으나 앞이 마에 이식한 결과 사슴뿔은 자라는 도중에 부 러져서 녹용을 절각하여 생산량을 조사하였다. 꽃사슴 1 두와 레드디어는 1 두는 자연낙각 후의 무게를 조사하였다.

\section{II. 결과 및 고찰}

\section{1. 조직판의 발달}

사슴뿔 이식 후 조직판의 발육상황은 Table 2 에서 보는 바와 같다. 조직판(flap)은 육경(pedicle) 의 길이가 $1 \mathrm{~cm}$ 에서 $3 \mathrm{~cm}$ 정도 되었을 때 육경 의 원위부 첨단을 두께 $0.4 \sim 0.5 \mathrm{~cm}$ 로 채취하여 이식하였다. 육경에 이식한 6 마리 중 꽃사슴 1 두만이 이식 후 $2 \mathrm{~cm}$ 정도 성장하였으나 엘크 2 두와 레드디어 2 두의 이식한 조직판은 발달하 지 못하였으며, 녹용 채취시 이식부위에 약간 의 돌기가 있는 정도였다. 본 시험에서 육경에 이식한 조직판의 발달이 낮은 이유는 정확하게 규정하기는 어렵지만 채취한 조직판을 아래에 남아있는 육경자체에 이식하기가 어려웠다. 왜 냐하면 육경의 둘레는 둥글고 이 부위에 조직 판을 이식하기 위해서는 남아있는 육경의 둘레 에 이식판을 붙일 수 있게 육경피부를 둥글게 삭제해야하는데 막 자라고 있는 육경의 피부를 
Table 2. Pedicle development and growth after flap-grafting by species

\begin{tabular}{ccccc}
\hline Item & Region of grafting & Sika & Red & Elk \\
\hline \hline No. of deer & On the pedicle & 4 & 4 & 4 \\
No. of pedicle growth & Middle line of the skull & 1 & 0 & 0 \\
& On the pedicle & 1 & 1 & 1 \\
\multirow{2}{*}{ No. of antler growth } & Middle line of the skull & 2 & 1 & 0 \\
&
\end{tabular}

삭제하는 작업과 둥근면에 조직판을 붙이기가 어려웠으며, 이로 인하여 완벽한 이식이 되지 못한 것으로 생각된다. 또한 전두골 정중선 중 앙에 이식한 6두는 꽃사슴(Cervus nippon) 2두와 레드디어 1 및 엘크 1 두에서 $2 \mathrm{~cm}$ 정도의 조직 판이 성장하여 이식한 부위의 육경이 형성되었 다고 볼 수 있다. 전두골 정중선 부위는 평평 하여 정확하게 이식할 조직판의 직경만큼 이식
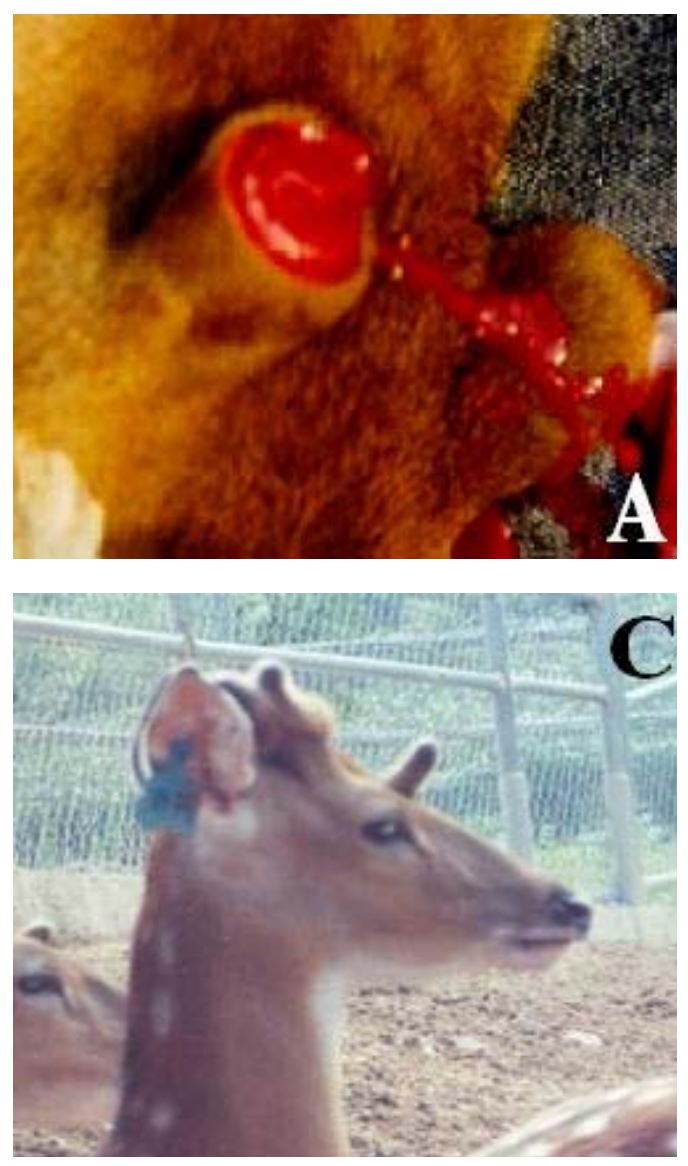

Fig. 2. (A): Amputated pedicle for frap-grafting, (C) : frap-grafted antler in forehead,
부위의 피부를 삭제하기가 쉬었고 이식작업도 육경쪽 보다는 쉬웠다. 제일먼저 전두골 정중 선 중앙에 이식한 조직판의 성장을 확인하기 위하여 이식한 조직판이 $5 \mathrm{~cm}$ 정도 자랐을 때 마취를 하여 확인한 결과, 이식한 조직판은 두 개골에 밀착되지 못하고 손으로 움직이면 흔들 릴 정도였다(Fig. 2D). 이것은 이식한 조직판과 두개골 사이에 피부의 진피가 제거되지 않아서
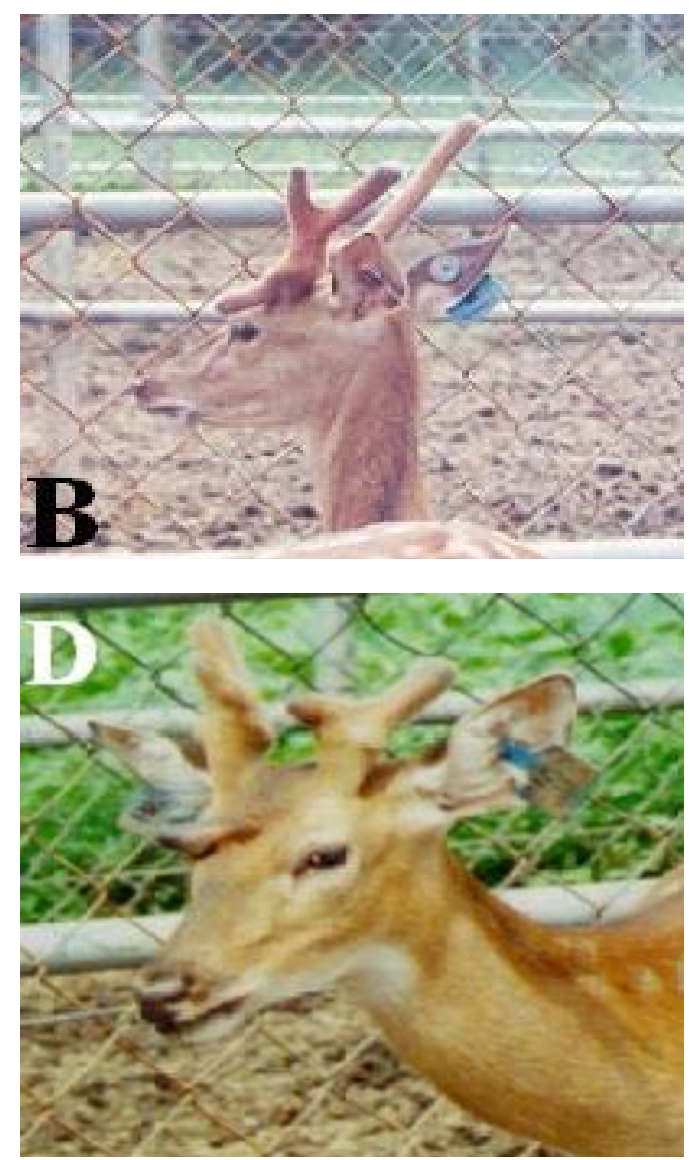

(B) : growth of frap-grafted antler in sika deer, (D) : frap-grafted antler which was not fixed in forehead skin. 
나타난 현상이라 생각되며 육경의 조직판은 두개골의 피부에서도 성장이 가능하다는 것을 보여준다. 이 후 이식부위의 두개골 피부를 진 피까지 완전히 제거한 후 다시 메스를 이용하 여 두개골의 골막과 두개골에 상처를 주어 이 식 후 조직판이 두개골에 밀착되게 시술을 하 였다. 이 결과 정중선에 이식한 조직판은 사슴 뿔로 분화 후 다음해 낙각이 될 때까지 단단 하게 붙어있었다. $2 \mathrm{~cm}$ 이상의 길이성장을 한 조직판은 계속 자라서 사슴뿔로 분화하였다. 본 시험에서 조직판 이식은 12 두 중 5 두가 뿔 로 발달하여 $42 \%$ 의 성공률을 보였으며, 이결 과를 종합해보면 사슴의 육경 조직판은 규정장 소가 아닌 아마의 다른 부위에서도 성장이 가 능하다는 것을 보여준다. 이는 Jaczewki (1961, 1967)가 휄로우디어에서 육경 전체를 이마에 이식하여 4개의 뿔 생산을 한 시험과 비슷하며, Hartwig (1968) 및 Hartwig와 Schrudde (1974)이 노루의 정수리 뼈와 이마에 이식을 성공하였는 데 이들이 이식한 조직판은 피부가 없는 조직 판을 이식한 것이 본시험과는 다르다. Goss와 Powell (1985)은 전두골 골막 조직판을 휄로우 디어의 앞다리 장골에 직경 $1.5 \mathrm{~cm}$ 골막을 이 식하여 육경뼈로 분화하고 작은 뿔의 성장을 유도했다고 하였다. 이처럼 육경의 골막은 특 히 전두골 주위에서 성장의 잠재력이 가장 높 다고 할 수 있겠다.

\section{2. 조직판 채취와 녹용 생산량}

이식을 위하여 조직판을 제공한 자리와 자연 상태인 반대편 대조구의 녹용 생산량을 Table 3 에 나타내었다. 조직판을 제공한 자리와 대조
구의 첫 뿔의 녹용 생산은 $540 \mathrm{~g}$ 과 $333 \mathrm{~g}$ 이었 으며, 재생 뿔의 생산량은 $531 \mathrm{~g}$ 및 $383 \mathrm{~g}$ 으로 첫 뿔(spike)과 재생 뿔의 발생량은 조직판을 제공한 쪽이 더 많았다 $(\mathrm{P}<0.05)$. 이는 Goss와 Powell (1985)의 조직판 이식 시험에서 직경이 $1.5 \sim 1.05 \mathrm{~cm}$ 인 조직판을 제공한 자리에서는 20 $\%$ 의 뿔이 생산되었고 $0.75 \sim 0.4 \mathrm{~cm}$ 의 조직판을 제공한 자리는 전체의 $80 \sim 100 \%$ 뿔이 자랐다 고 하여 조직판의 직경을 크게 하여 제공하면 사슴뿔의 생산이 안 되는 경우가 있다고 하였 으나, 본 시험에서는 조직판의 두께를 $0.4 \sim 0.5$ $\mathrm{cm}$ 의 범위로 채취하였지만 뿔 생산이 안 되는 쪽은 없었고 오히려 조직판을 제공한 쪽이 반 대쪽보다 녹용의 생산량이 더 많았다. 이는 적 당한 외상의 자극이 육경을 자극하여 사슴뿔이 더 생산된 것으로 보이며 이 외상 자극에 의한 뿔 성장은 많은 연구자들에 의해 확인되었다 (Jaczewski 등, 1976; Jaczewski, 1981b; Lincoln과 Fletcher, 1976; Bubenik 등, 1988).

\section{3. 조직판의 발육성적}

육경의 조직판을 이식하여 사슴뿔로 분화후 의 성적은 Table 4 에서 보는 바와 같이 이식한 조직판이 녹용으로 분화한 개체에서 엘크는 길 이 $17 \mathrm{~cm}$ 를 나타내었고 녹용 생산량은 $302 \mathrm{~g}$, 가지 수는 2 개였다. 이 뿔은 앞이마의 정중선 중앙에 이식한 관계로 먹이를 먹다가 사슴뿔이 부러졌다(Fig. 4). 물리적 구조상 앞이마에 정중 선에 이식하면 돌출하는 뿔 때문에 먹이를 먹 을 수가 없게 된다. 이 결과는 Jaczewski (1961) 의 실험에서도 이마에 이식한 뿔은 일정수준의 길이로 성장 후에 부러진 사례와 같다. 이 뿔

Table 3. Means and standard deviation of antler yield after pedicle amputation in red deer

\begin{tabular}{lcc}
\hline Item & Control & Pedicle amputation \\
\hline \hline Spike weight (g) & $333 \pm 60^{\mathrm{a}}$ & $540 \pm 61^{\mathrm{b}}$ \\
Regenerated antler weight (g) & $383 \pm 46^{\mathrm{a}}$ & $531 \pm 51^{\mathrm{b}}$ \\
Total yield (g) & $716 \pm 56^{\mathrm{a}}$ & $1,071 \pm 42^{\mathrm{b}}$ \\
Rate (\%) & 100 & 150 \\
\hline
\end{tabular}

${ }^{\mathrm{a}, \mathrm{b}}$ Means with different superscripts in the same column are significantly different $(\mathrm{P}<0.05)$. 
Table 4. Velvet antler length and weight of flap-grafted region by species

\begin{tabular}{ccccc}
\hline & & \multicolumn{2}{c}{ Antler } & \multirow{2}{*}{$\begin{array}{c}\text { No. of } \\
\text { point }\end{array}$} \\
\cline { 3 - 5 } & Types of antler & Length $(\mathrm{cm})$ & Weight $(\mathrm{g})$ & 302 \\
Elk & Velvet antler & 17 & 122 & 2 \\
Red deer & Hard antler & 26 & 26 & 1 \\
Sika deer & Hard antler & 7 & 1 \\
\hline
\end{tabular}

의 가지는 지면과 수평의 모양으로 자랐는데, 이는 Goss(1991)가 fallow deer의 뿔 발생 골막 (AP)을 처음의 정위에서 $180^{\circ}$ 회전 시켰을 때, 그 후에 형성된 초기 두개골 부가물과 재생된 뿔은 앞뒤가 뒤바뀐 정반대의 모양으로 자랐다 고 하였으며 사슴뿔 가지의 방향은 이미 육경 의 골막 안에 정보가 있다고 하였는데, 본 시 험에서도 이식된 조직판이 잘려진 정위에서 이 식될 때 방향이 약간 돌아간 상태에서 접목된 결과라고 생각된다. 레드디어의 조직판은 이마 의 정중선 위쪽 좌우 뿔의 중앙 정수리에 이식 되었는데 이 뿔은 절각을 하지 않고 낙각이 될 때까지 놓아두었다. 그 결과 낙각된 사슴뿔은 길이 $26 \mathrm{~cm}$ 에 무게 $122 \mathrm{~g}$ 의 사슴뿔로 성장하였 다. 그런데 이 뿔은 Fig. 3처럼 앞으로 휘어져 자랐다. 이 결과의 원인이 무엇인지는 정확하 게 알 수는 없었다. 만일 이식된 조직판이 자 라면서 사슴뿔이 부러졌다면 외부적으로 발견 을 하였을 텐데 $5 \mathrm{~cm}$ 정도의 길이성장 후부터 는 사슴뿔이 앞쪽으로 휘어져서 자랐기 때문이
다.

이마의 피부에 이식된 꽃사슴(Cervus nippon) 의 조직판은 결국 길이 $7 \mathrm{~cm}$ 상태에서 성장을 멈추고 다음번 낙각시기에 낙각이 되었다. 이 때 뿔 길이는 $7 \mathrm{~cm}$ 에 무게 $26 \mathrm{~g}$ 의 녹용으로 성 장하였고, 꽃사슴 1 두는 $5 \mathrm{~cm}$ 정도의 길이 성 장 후 다음번 뿔 주기에서 자연낙각이 되었으 나 불행하게도 낙각 된 뿔을 찾지 못했다. 육 경 자체에 이식한 꽃사슴의 뿔은 길이성장이 7 $\mathrm{cm}$ 무게가 $32 \mathrm{~g}$ 이었다(Fig. 2). 전두골에 이식 하여 녹용으로 분화한 꽃사슴 2 두와 레드디어 1 두 및 엘크 1 두는 다음번 뿔 주기에서 모두 낙각은 되었으나 재생 뿔의 발생이 없었다. 이 처럼 이식부위가 다음번 뿔 주기에서 재생을 하지 않은 정확한 원인은 알 수 없지만 $0.5 \mathrm{~cm}$ 정도의 육경 조직판 두께로 이식을 할 경우 첫 번째 주기에는 사슴뿔로 분화를 할 수가 있으 나 다음번 주기에서 뿔 재생이 되지 않은 것은 이식된 이마 부위의 그루터기 밑에 재생을 할 수 있을 정도의 충분한 육경 조직이 형성되지
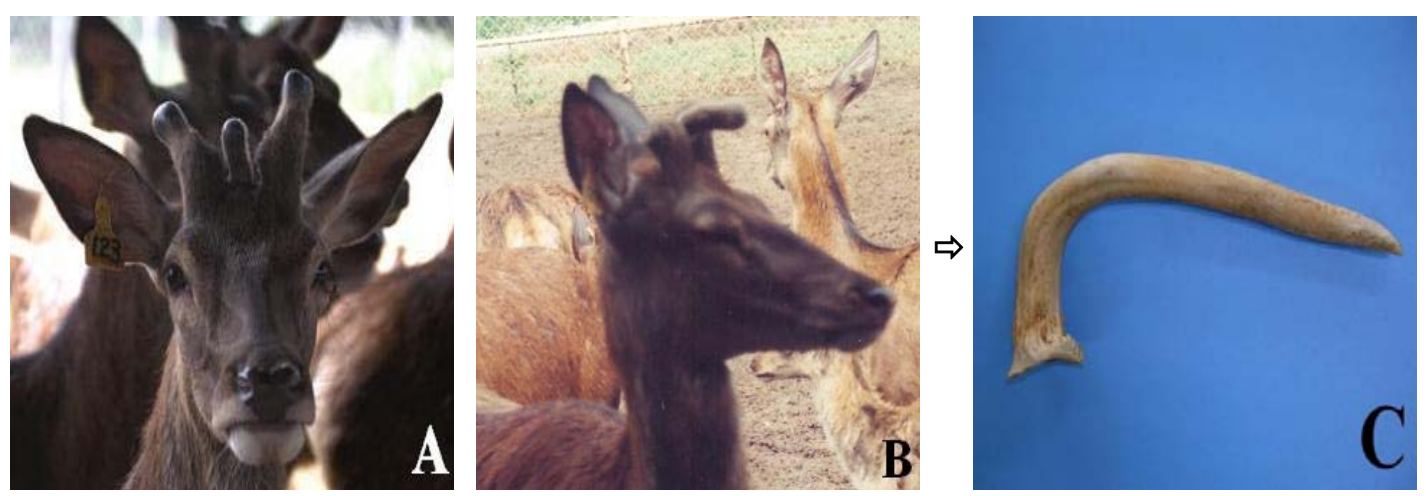

Fig. 3. Antler of red deer stag flap-grafted in midline of forehead,

(A) : 2-year-old Red deer stag with three antlers, $(B)$ : curved anlter of $(A)$,

(C) : hard antler natural cast of $(A), 26 \mathrm{~cm}, 122 \mathrm{~g}$. 

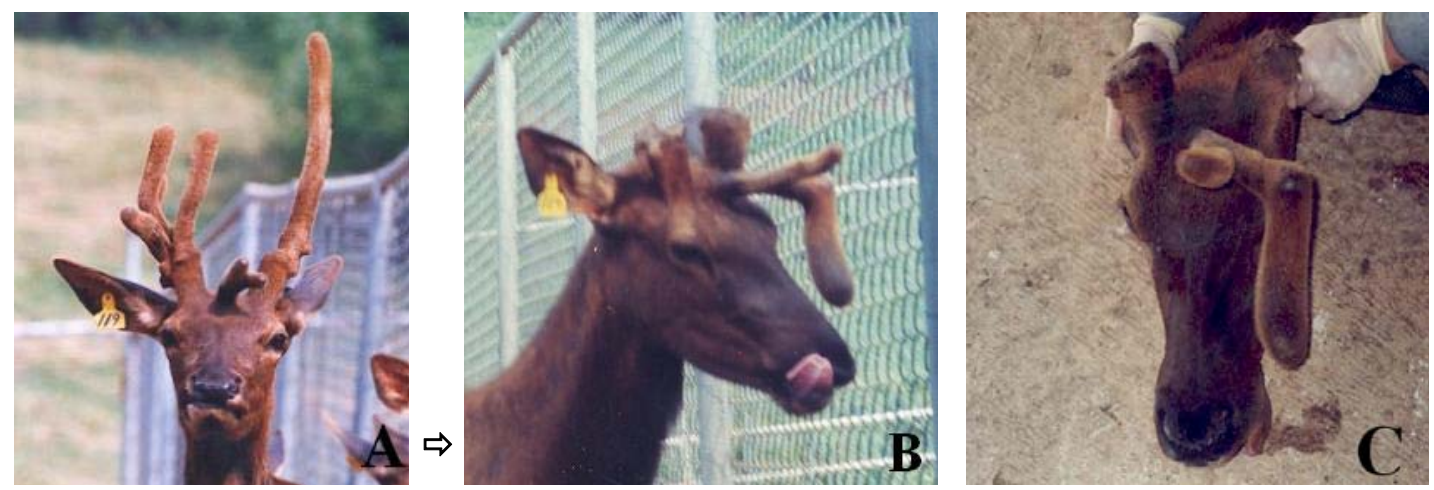

Fig. 4. 2-year-old elk deer bull with three antlers flap-grafted (A): Three points of right velvet anlter whose pedicle was amputated, (B): flap-grafted velvet antler which has two points in midline of forehead, $17 \mathrm{~cm}, 302 \mathrm{~g},(\mathrm{C})$ : bigger point of antler grafted in frontal bone became broken.

않았을 것으로 생각되며, 이는 Jaczewski (1967) 가 보고한 뿔 주기의 불규칙성과 비슷하다고 할 수 있겠으며, 이 문제는 앞으로 더 연구되 어져야 할 과제이다.

$$
\text { IV. 요 약 }
$$

본 연구는 육경 조직판 이식이 사슴뿔의 성 장에 미치는 영향을 구명하기 위하여 육경 조 직판을 육경과 전두골 정중선 부위에 각각 이 식 하였을 때 조직판의 발달, 조직판을 제공한 부위의 녹용 생산량 및 이식한 조직판의 발육 성적을 조사하였으며, 그 결과를 요약하면 다 음과 같다. 사슴뿔의 조직판 이식은 육경과 전 두골 정중선 중앙과 좌우 양 뿔의 정수리에 이 식 시 이식 성공률은 12 두 중 5 두로 $42 \%$ 이었 다. 사슴뿔의 발생 정규부위가 아닌 사슴의 전 두골에서 조직판 이식으로 추가적인 사슴뿔 발 생을 유도할 수가 있었다. 레드디어의 경우 대 조구와 조직판을 제공한 쪽의 녹용 총생산량은 각각 $716,1,071 \mathrm{~g}$ 으로 이식을 하기 위하여 절 단된 쪽의 녹용 생산량이 더 많았으며, 가짓수 도 조직판을 제공한 쪽이 2.3개로 대조구 1 개 보다 많았다. 엘크의 경우 1 두에서 이마에 조 직판이 이식된 뿔에서 길이 $17 \mathrm{~cm}$, 무게 $302 \mathrm{~g}$ 녹용을 생산하였으며, 레드디어는 다음해 낙각 된 녹각에서 길이 $26 \mathrm{~cm}$ 에 무게 $122 \mathrm{~g}$ 을 생산
하였다. 조직판 이식시 이식부위의 피부는 진 피까지 제거하여야만 두개골에 이식한 조직판 이 견고하게 부착되었다.

이상의 결과에서 조직판 이식으로 사슴뿔 발 생의 정규부위가 아닌 전두골에서 부가적인 사 슴뿔을 생산할 수 있다고 사료된다.

\section{V. 인 용 문 헌}

1. Bubenik, G. A., Bubenik, A. B., Stevens, E. D. and Binnington, A. G. 1982. The effect of neurogenic stimulation on the developement and growth of bony tissue. J. Exp. Zool. 219, 205-216.

2. Goss, R. J. 1965. Mammalian regeneration and its phylogenetic relationship, 33-38. In: V. Kiortsis and H. A. L. Trampusch (eds.), Regeneration in animals and Related Problems. North Holland Publ. Co., Amsterdam.

3. Goss, R. J. 1991. Induction of deer antlers by transplanted periosteum. III. Orientation. J. Exp. Zool. 259:246-251.

4. Goss, R. J. and Powel, R. S. 1985. Induction of antlers by transplanted periosteum. I. Graft size and shape. J. Exp. Zool. 235:359-373.

5. Hartwig, H. 1968. Durch Periostverlagerung experimentell erzeugte, heterotope Stirnzapfenbildung beim Reh. Z. Säugetierkunde 33:246-248. 
6. Hartwig, H. and Schrudde, J. 1974. Experimentelle Untersuchungen zur Bildung der primären Stirnauswüchse beim Reh (Capreolus capreolus L.) Z. Jagdwiss. 20:1-13.

7. Jaczewski, Z. 1956a. Free transplantation of antler in red deer (Cervus elaphus L.). Bull. Acad. Polon. Sci., Cl. II, 4:107-110.

8. Jaczewski, Z. 1956b. Further observations on transplantation of antler in red deer (Cervus elaphus L.). Bull. Acad. Polon. Sci., Cl. II, 4:289-291.

9. Jaczewski, Z. 1961. Observations on the regeneration and trans- plantation of antlers in deer, Cervidae. Fol. Biol. 9:47-99.
10. Jaczewski, Z. 1967. Regeneration and transplantation of antlers in deer, Cervidae. Z. Saugetierkd. 32:215-233.

11. Jaczewski, Z. 1976. The induction of antler growth in female red deer. Bull. de l'Académie Polonaise des Sciences. 21:61-65.

12. Jaczewski, Z. 1981b. Further observation on the induction of antler growth in red deer female. Folia Biol. 29:131-140.

13. Lincoln, G. A. and Fletcher, T. J. 1976. Induction of antler growth in a congenitally polled Scottish red deer stag. J. Exp. Zool. 195:247-262.

(접수일자 : 2006. 11. 6. / 채택일자 : 2006. 12. 6.) 